\title{
Angler exposure to domoic acid via consumption of contaminated fishes
}

\author{
Fernanda F. M. Mazzillo ${ }^{1, *}$, Caroline Pomeroy ${ }^{2}$, Julie Kuo ${ }^{1}$, Pete T. Ramondi ${ }^{3}$, \\ Raquel Prado ${ }^{4}$, Mary W. Silver ${ }^{1}$

\begin{abstract}
${ }^{1}$ Department of Ocean Sciences, University of California Santa Cruz, 1156 High Street, Santa Cruz, California 95064, USA CA 95076, USA

${ }^{3}$ Department of Ecology and Evolution, University of California Santa Cruz, Center for Ocean Health, 100 Shaffer Road, Santa Cruz, California 95064, USA

${ }^{4}$ Department of Applied Mathematics and Statistics, University of California Santa Cruz, 1156 High Street, Santa Cruz,
\end{abstract} \\ ${ }^{2}$ California Sea Grant Extension Program, University of California Cooperative Extension, 1432 Freedom Blvd, Watsonville, \\ California 95064, USA
}

\begin{abstract}
Domoic acid (DA) is a neurotoxin that causes amnesic shellfish poisoning, and fish are recognized vectors of DA to marine fauna. However, the exposure of anglers through consumption of DAcontaminated fish is unknown. We measured DA in 11 fish species targeted by Santa Cruz Wharf (SCW) anglers in Monterey Bay, California, USA, and surveyed anglers regarding their fish consumption patterns. In addition, we used California mussel Mytilus californianus DA data provided by the state of California and our measurements of DA in seawater to examine the associations between DA in fish viscera versus in mussels and seawater. DA was detected in the viscera of 7 fish species commonly consumed by anglers, and toxin uptake in fishes varied according to their diet. DA was almost entirely in the viscera, with low DA concentrations detected in muscle tissue. The majority of anglers (58\% of 565) reported consuming their catch, with a small fraction ingesting the viscera. Total DA concentrations in fish decreased significantly after 11 mo storage at $-20^{\circ} \mathrm{C}$. DA concentration in seawater and California mussels was correlated with DA in the viscera of some but not all fish groups. We conclude that SCW anglers who consume their catch are exposed to asymptomatic DA doses, and that exposure is a function of the species and parts consumed, as well as storage methods and DA levels in the seawater when the fish are caught.
\end{abstract}

KEY WORDS: Domoic acid - Human exposure • Recreational fishery · Anglers · Mytilus californianus · Pseudo-nitzschia · Monterey Bay

Resale or republication not permitted without written consent of the publisher

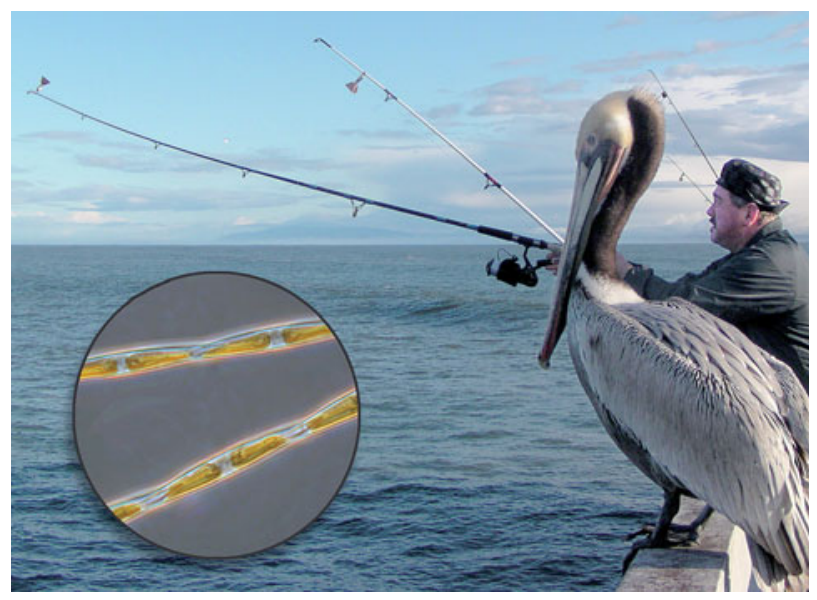

Fishing at the Santa Cruz Wharf: anglers who consume their fish catch may become contaminated with domoic acid, a neurotoxin produced by several species of Pseudo-nitzschia (inset).

Photos: Fernanda Mazzillo, Rozalind Jester (inset)

\section{INTRODUCTION}

Domoic acid (DA) is a hydrophilic neurotoxin produced by diatoms of the genus Pseudo-nitzschia and the cause of amnesic shellfish poisoning (ASP) in humans (Bates et al. 1989). Humans are exposed to the toxin by consuming DA-contaminated shellfish (Waldichuk 1989, Wright et al. 1989). ASP symptoms vary according to the ingested DA dose and include vomiting and diarrhea, with higher exposures potentially leading to neurological effects such as disorienta- 
tion, seizure, short-term memory loss and, in extreme cases, death (Pulido 2008). The first documented case of ASP occurred in 1987 in Prince Edward Island, Canada. At that time, 108 persons who consumed DA-contaminated blue mussels Mytilus edulis were diagnosed with ASP symptoms; 3 of them died (Perl et al. 1990). The estimated DA dose ingested by victims in this event ranged between 60 and $290 \mathrm{mg}$ (Jeffery et al. 2004).

DA was discovered in California in 1991 and the California Department of Public Health (CDPH) subsequently added DA to the phycotoxins monitored in California mussels Mytilus californianus as part of the Preharvest Shellfish and Marine Biotoxin Monitoring Program. This program appears to have been effective in protecting consumers of commercially and recreationally caught shellfish, since no ASP cases have been reported in California even though toxin levels in local waters have occasionally been high. However, DA also can be transferred from Pseudo-nitzschia to fish, which can contaminate marine birds such as brown pelicans Pelecanus occidentalis and Brant's cormorants Phalacrocorax penicillatus, and marine mammals such as California sea lions Zalophus californianus, which prey upon the contaminated fish (Work et al. 1993, Lefebvre et al. 1999, Scholin et al. 2000). Presently, there is no formal monitoring of DA in recreationally caught fish (G. Langlois pers. comm.), yet DA has been found in fishes at locations where anglers fish (Fire \& Silver 2005). Thus, humans may be exposed to DA through consumption of not only shellfish but also recreationally caught finfish.

In addition, DA has been detected in fish species that are commonly targeted by California anglers (SCCWRP \& MBC 1994, RecFIN 2009). The planktivorous northern anchovy Engraulis mordax and Pacific sardine Sardinops sagax have been found to contain DA on the California and Portuguese coasts, respectively (Vale \& Sampayo 2001, Lefebvre et al. 2002). Larger pelagic fish such as Pacific mackerel Scomber japonicus and jack mackerel Trachurus symmetricus, which feed on both plankton and small planktivorous fishes, also contain DA off Mexico and Southern California, respectively (Sierra-Beltran et al. 1998, Busse et al. 2006). Likewise, DA has been documented in the viscera of several benthic-feeding flatfish species found offshore in the Central California area (Vigilant \& Silver 2007).

DA contamination of fish can occur through different pathways; hence the presence of DA in fish may or may not be in phase with the local presence of toxic Pseudo-nitzschia in seawater. For example, planktivorous fish acquire DA by feeding directly on toxic Pseudo-nitzschia, but typically only when its density exceeds $\sim 1000$ cells $~^{-1}$ (Lefebvre et al. 2002a). In contrast, benthic-feeding flatfish are likely to acquire DA by feeding on infaunal and/or epifaunal organisms and on DA-contaminated sediment (Vigilant \& Silver 2007). Because different sources of DA have been identified for different fish species, a range of DA levels may be encountered in fish collected at the same time. Identifying an association between DA in seawater and in fish is important for predicting the occurrence of DA in fish. It is equally important to evaluate whether mussels used in California's Marine Biotoxin Monitoring Program can be used to predict the occurrence of DA in fish.

DA distribution and degradation in the fish body is also poorly understood, mostly because initial studies (Lefebvre et al. 1999, Scholin et al. 2000) were focused on DA exposure of marine animals such as California sea lions, which consume whole fish. In contrast, anglers, depending on their cultural background and other factors, may prepare and consume fish in different ways, including eating different body parts and storing their catch for different lengths of time. Thus, understanding angler consumption patterns as well as DA distribution in the fish body and DA degradation during storage are of paramount importance in order to evaluate exposure of anglers.

The goals of the present study were to (1) determine which fish species and body parts are consumed by anglers, and how anglers store their catch; (2) measure DA in fish commonly caught by anglers and compare DA levels among fish species with different diets to identify those that pose the greatest threat to anglers; (3) measure and compare DA levels in fish viscera and muscle tissue under different storage conditions to determine if DA diffusion and degradation occur during storage; and (4) assess possible relationships between DA in fish viscera and in seawater collected nearshore and offshore, as well as DA in CDPH mussels to verify whether the presence of DA in fish can be predicted by the occurrence of DA in seawater and in mussels.

We focused the present study on the Santa Cruz Wharf (SCW) in Monterey Bay, California, because it supports a sizeable recreational fishery (W. Van Buskirk pers. comm.) and is easily accessed by anglers. Additionally, the SCW is a site where CDPH mussels are harvested and toxic blooms of Pseudo-nitzschia are frequent.

\section{MATERIALS AND METHODS}

Angler survey. We conducted an intercept survey of SCW anglers to determine whether they were at risk of exposure to DA toxins as a result of their consumption of SCW-caught fish. The survey was modeled after the Santa Monica Bay and San Francisco Bay seafood con- 
sumption studies (SCCWRP \& MBC 1994, SFEI 2000) and informed by similar studies done elsewhere in the USA (e.g. the Great Lakes: West 1992; New York: Connelly et al. 1996). An intercept survey, a type of faceto-face interview, is the most effective survey method for this context because it affords more complete coverage of anglers, including those who lack a telephone or permanent address, or do not speak or read English (US EPA 1998). In addition, no fishing license is required to fish from manmade structures in California, thus intercept surveys are the only way to reliably identify and sample the population. In addition, this facilitates the collection of more accurate and reliable data because it allows the researcher to: (1) clarify questions and responses, and (2) make on-site observations that contribute to more accurate and consistent identification of anglers' catch (US EPA 1998).

The survey consisted of 3 components: (1) an initial census at the SCW to determine spatial and temporal patterns of angler use; (2) an initial contact with potential interviewees to determine willingness to participate, and to prevent duplicate interviews; and (3) a survey questionnaire, administered as an in-person interview. The survey sought to determine the proportion of anglers that consume their catch and their consumption patterns. Thus, the questionnaire included questions on species and parts consumed (i.e. muscle tissue, viscera) and catch storage and use. A fish identification booklet was developed and used to increase the accuracy of species identification by anglers. As used here, the term viscera refers to all organs associated with the digestive tract, whereas the term muscle tissue includes the edible meat, and excludes blood, skin, head, tail, gonads and viscera.

The survey protocol and questionnaire were pretested and revised before being applied in the field for a 12 mo period beginning in May 2007. The survey was conducted by a team of 2 interviewers per shift, from a total of 23 interviewers selected and trained to conduct the survey. Survey shifts lasted 2 to $2.5 \mathrm{~h}$ and occurred twice per day on 1 weekday and 1 weekend day per week. Survey data were processed and analyzed using PASW Statistics 17.0 to quantify anglers who reported consuming their catch, and of those, the number of consumers by species, the parts consumed and storage method by species.

Sample collection. In parallel with the angler survey, fish, seawater and mussel samples were collected at the SCW weekly from January 2007 through October 2008 and in May 2009. Fish, seawater and mussel samples were not necessarily collected on the same day, but seawater and mussel samples used for comparisons were collected within $7 \mathrm{~d}$ of the fish capture date. Bagged mussels Mytilus californianus deployed from the SCW were collected and processed as described in Jester et al. (2009). Seawater samples were collected with a surface bucket at the SCW $\left(36.57^{\circ} \mathrm{N}, 122.01^{\circ} \mathrm{W}\right)$. Additional surface samples were collected at M1, an offshore mooring located in the center of Monterey Bay over $1000 \mathrm{~m}$ deep water $\left(36.74^{\circ} \mathrm{N}, 122.02^{\circ} \mathrm{W}\right)$, because some of the fish species range more widely in the Bay outside the wharf region (Fig. 1). For determination of particulate DA in the seawater, $500 \mathrm{ml}$ were filtered through Whatman GF/F filters using a low vacuum pump system. The filters were subsequently stored at $-20^{\circ} \mathrm{C}$ for 2 mo before analysis.

Fish were collected using hook-and-line gear from the SCW (total of $352 \mathrm{~h}$ of fishing effort). Twelve volunteers were trained to use angler fishing techniques. Fish caught were placed immediately in a cooler with ice. Total length, weight and species were recorded and the fish were dissected at the wharf approximately within the next $5 \mathrm{~h}$ to prevent possible diffusion of DA from the viscera into the muscle tissue. All dissected fish and viscera were stored at $-20^{\circ} \mathrm{C}$ for $1 \mathrm{wk}$ or for a maximum period of 2 mo prior to stomach content analyses and toxin extraction, with the exception of jacksmelt muscle tissue samples, which were stored between 6 and 12 mo.

In addition to the anchovies and sardines caught at the SCW, these were also acquired in March and April

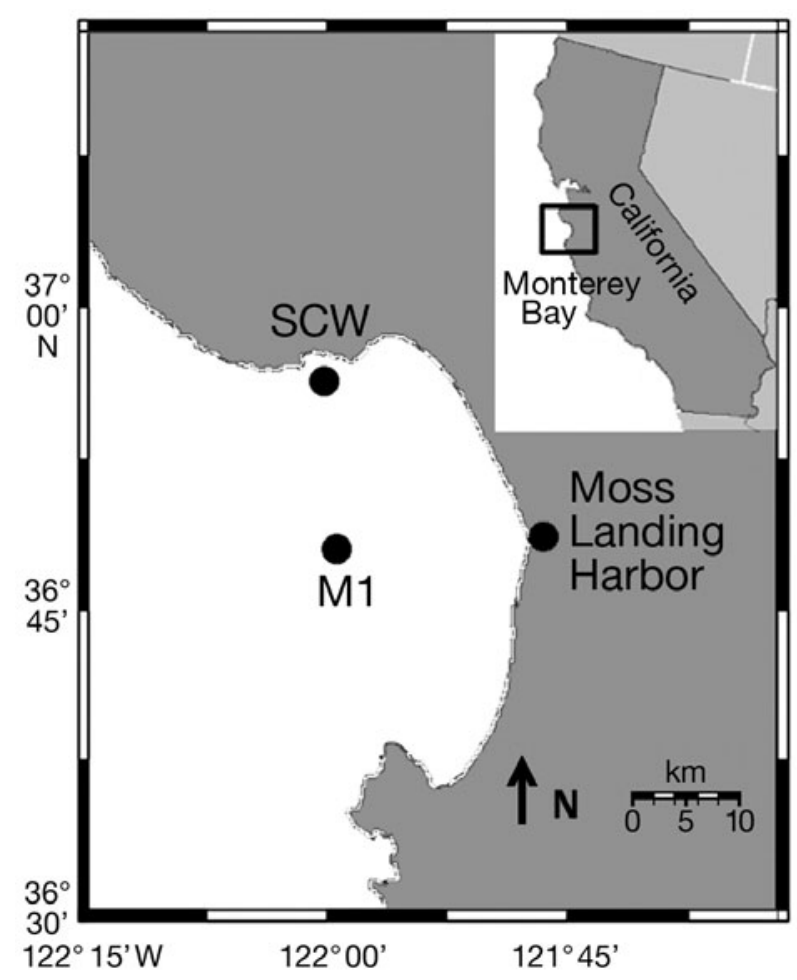

Fig. 1. Monterey Bay, California, showing sampling sites: Santa Cruz Wharf (SCW), offshore mooring (M1) and Moss Landing Harbor, where vessel-caught fish were obtained 
2008 (anchovies) and in July and August 2008 (sardines) from commercial fishing boats based at Moss Landing Harbor (Fig. 1). These fish were caught at various locations in Monterey Bay; the exact location of the catch is proprietary information of the catch vessels. The fish were kept in ice on the vessel for approximately $5 \mathrm{~h}$ until they were retrieved by scientists. Once retrieved, fish were treated as wharf-caught fish described above, except that they were dissected in the laboratory within the next $2 \mathrm{~h}$ (i.e. total of approximately $7 \mathrm{~h}$ before dissection). These additional $2 \mathrm{~h}$ are unimportant for diffusion of DA in the fish since the specimens were kept in ice continually, minimizing diffusion rates.

Fish feeding habits. Fish feeding habits were determined by examining the stomach contents of each fish species. Observations were made on both a dissecting microscope (Olympus SZH Stereozoom) and a Zeiss Axiovert compound light microscope. Prey items were identified to the highest level of classification possible. After stomach content observations were completed, toxin extraction followed.

DA in mussels. Mussel DA data were extracted from the monthly CDPH Marine Biotoxin reports (www. cdph.ca.gov/healthinfo/environhealth/water/Pages/ Shellfish.aspx). CDPH measured DA using HPLC and used a reporting limit of detection (LOD) of $2.5 \mu \mathrm{g}$ DA $\mathrm{g}^{-1}$ mussel tissue (G. Langlois pers. comm.).

DA in fish. DA was measured in fish viscera using 2 methods: HPLC and Rapid ELISA (Mercury Science). Both methods are comparable, but ELISA is a more desirable method due to its lower LOD and faster, more cost-effective procedure (Litaker et al. 2008). DA was measured with ELISA in the following fish samples: (1) all muscle tissue samples, except for anchovy collected in 2007, when DA in muscle tissue was measured using HPLC ; $_{(2)}$ viscera of 6 sardine specimens examined in the DA degradation and diffusion experiment; and (3) fish collected in May 2009. The HPLC method was used to measure DA in all other fish viscera samples.

For both methods, fish viscera samples were prepared as $4 \mathrm{~g}$ of pooled composite from multiple fish specimens, unless the individual fish viscera weighed $>4 \mathrm{~g}$, in which case the viscera from a single specimen were analyzed. Samples were homogenized with a hand-held tissue homogenizer (Tissue Miser, model PNF2110, Fisher Scientific), and after $16 \mathrm{ml}$ of 50:50 $\mathrm{MeOH}$ :Nanopure water was added, samples were sonicated with a Sonifier cell disruptor (Model W185D, Branson Sonic Power) and centrifuged for $20 \mathrm{~min}$ at $3800 \mathrm{rpm}(1698 \times g)$. The supernatants were then filtered through a $3 \mu \mathrm{m}$ polycarbonate filter.

For HPLC analyses, the filtrate was cleaned for interfering compounds using solid phase extraction (SPE) columns (J. T. Baker) (Hatfield et al. 1994, Quilliam et al. 1995). DA recovery from SPE columns (lot no. E03553) was determined by spike and recovery experiments using $90 \%$ pure DA reagent (Sigma) and 10\% methanol (Fisher Scientific). Results indicated that an average of $97 \%$ of DA was recovered (SD $=3.3 \%, \mathrm{~N}=$ $3)$. An average of $84 \%(\mathrm{SD}=7.4 \%, \mathrm{~N}=4)$ of $\mathrm{DA}$ recovery from SPE columns was calculated for fish viscera (anchovy and flatfish) based on previous studies that followed the same extraction procedures in our laboratory (Lefebvre et al. 1999, 2001, 2002a, Vigilant \& Silver 2007). DA values reported here are uncorrected for possible loss during extraction and clean up. DA analyses were conducted using an isocratic gradient profile on a Hewlett-Packard 1050 HPLC according to Vigilant \& Silver (2007). The DA LOD was $0.2 \mu \mathrm{g} \mathrm{ml}^{-1}$ (ppm).

For ELISA analyses, the filtrate was diluted at 1:100 and 1:1000 in the buffer solution provided in the ELISA kit. The diluted samples were used in the ELISA plates following the protocol accompanying the kit. An EMax Precision Microplate Reader (Model E10968, Molecular Devices) was used to measure absorbance at $450 \mathrm{~nm}$. The ELISA detection limit was $0.1 \mathrm{\mu g} \mathrm{l}^{-1}$ (ppb).

DA in seawater. Particulate DA in phytoplankton seawater samples was measured when toxic Pseudo-

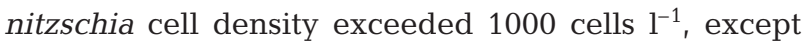
during summer 2008 (>100 cells ${ }^{-1}$; cell density data not reported here). Particulate DA was measured with HPLC in all samples collected between January 2007 and October 2008 and ELISA was used for samples collected in May 2009; $10 \% \mathrm{MeOH}$ was used to extract DA from Whatman GF/F filters. For HPLC analyses, particulate DA was analyzed by the 9 fluorenylmethoxycarboxyl (FMOC) procedure (Pocklington et al. 1990) and equipment was used as described by Vigilant \& Silver (2007). The DA LOD for phytoplankton samples was $0.06 \mathrm{ng} \mathrm{ml}^{-1}$. For ELISA analyses, seawater sample filtrates were prepared as for fish sample filtrate described above.

DA degradation and diffusion in the fish body. Vessel-caught Pacific sardine specimens were used for DA degradation and diffusion experiments in fish. To verify whether DA can diffuse from the viscera into the muscle tissue and whether DA degraded during the 11 mo storage period, these specimens were stored in 2 ways: (1) dissected approximately $7 \mathrm{~h}$ after capture and stored at $-20^{\circ} \mathrm{C} \leq 2 \mathrm{mo}$ prior to DA analyses $(\mathrm{N}=22)$, or (2) frozen whole and dissected and analyzed for DA $11 \mathrm{mo}$ after capture $(\mathrm{N}=5)$. DA levels in viscera and muscle tissue of specimens dissected $7 \mathrm{~h}$ upon capture and stored for $\leq 2$ mo were compared to DA levels in viscera and muscle tissue of the sardine stored whole for $11 \mathrm{mo}$. We measured DA in the muscle tissue of the same specimen for which we also obtained DA estimates in the viscera. 
Statistical analyses. Systat 10.0 was used for all statistical comparisons. Chi-squared and Fisher's exact tests were used to test whether the presence of DA in the fish viscera was associated with the presence of DA in seawater samples (nearshore and offshore) and in mussels collected within $7 \mathrm{~d}$ of fish capture. ANOVA was used to determine whether DA levels varied significantly among the 3 fish feeding groups (i.e. pelagic planktivores, pelagic omnivores and benthic feeders). Tukey's pairwise comparisons were subsequently used to determine which pairs of fish feeding groups had mean DA levels that significantly differed from each other. Linear regression was used to evaluate whether DA in muscle tissue of Pacific sardines was correlated with DA levels in their viscera. Finally, ANOVA tested whether DA in muscle tissue and viscera of sardines varied significantly between dissected sardine stored at $-20^{\circ} \mathrm{C}$ for $2 \mathrm{mo}$ and intact sardines stored for 11 mo. DA levels in muscle and viscera were $\log (x+1)$ transformed for linear regression and for ANOVA to comply with linearity and normality assumptions of the respective tests.

\section{RESULTS}

\section{Angler consumption patterns}

A total of 746 anglers were surveyed at the SCW over a 1 yr period; 565 reported fishing previously at the SCW. Of those, 58\% reported consuming their catch and $56 \%$ (318 anglers) reported consuming one or more of the species tested for DA content (Fig. 2). All consumers reported eating the muscle tissue. A small percentage (between 1.4 and $7.9 \%$ ) reported not removing the viscera before preparing their catch for consumption, which is important since DA may diffuse throughout the fish body depending on fish preparation method. These fish included the 2 most consumed species (i.e. jacksmelt and Pacific mackerel) and also the species with the highest DA levels detected during the present study (i.e. anchovy and sardine) (Fig. 3). In response to a separate question, some of these individuals also reported eating the viscera (Fig. 3).

Of those anglers who consume their catch, 55\% reported using their catch the same day that the fish was caught and $45 \%$ reported freezing their catch for later consumption. Anglers reported freezing their catch whole or partitioned (i.e. viscera removed prior to freezing). Among the species most consumed (i.e. jacksmelt and Pacific mackerel) and the species that contained the highest DA levels (i.e. anchovies and sardines), only $1.03 \%$ of jacksmelt consumers and $0.65 \%$ of Pacific mackerel consumers reported freez-

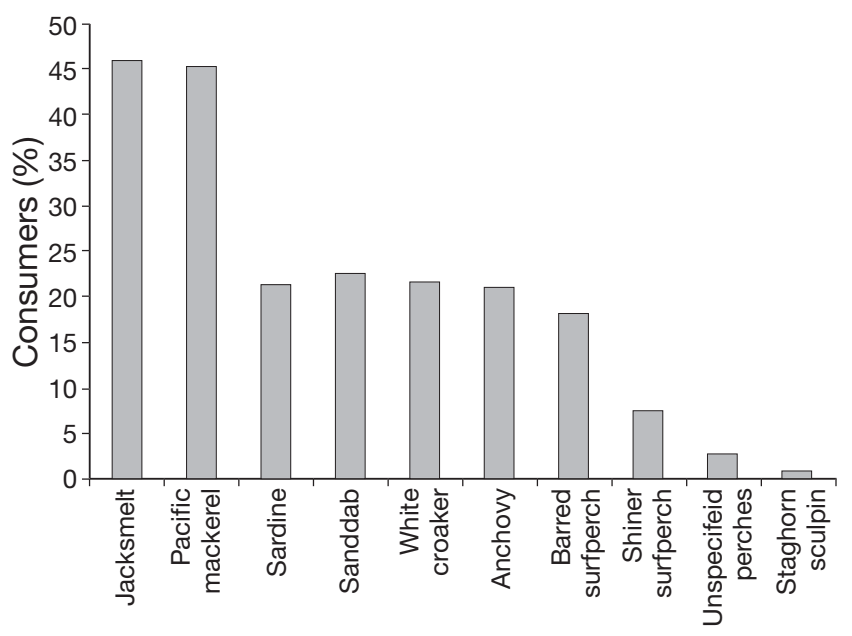

Fig. 2. Most commonly consumed fish species caught by Santa Cruz Wharf $(\mathrm{SCW})$ anglers $(\mathrm{N}=318)$

ing their catch whole (for an unknown period of time) and partitioning it at the time of consumption. All consumers of sardine and anchovy reported removing the viscera before freezing their catch for later consumption.

\section{DA in fish with different feeding habits}

For the toxin study, 11 species were caught. These finfish species were assigned to the following categories according to their feeding habits, based on examination of stomach contents: (1) pelagic planktivores, (2) pelagic omnivores and (3) benthic feeders (Table 1). All species caught were shown to have detectable DA levels at least once, except for barred surfperch, shiner surfperch, spotfin surfperch and white croaker, which did not contain measurable DA levels (Table 2).

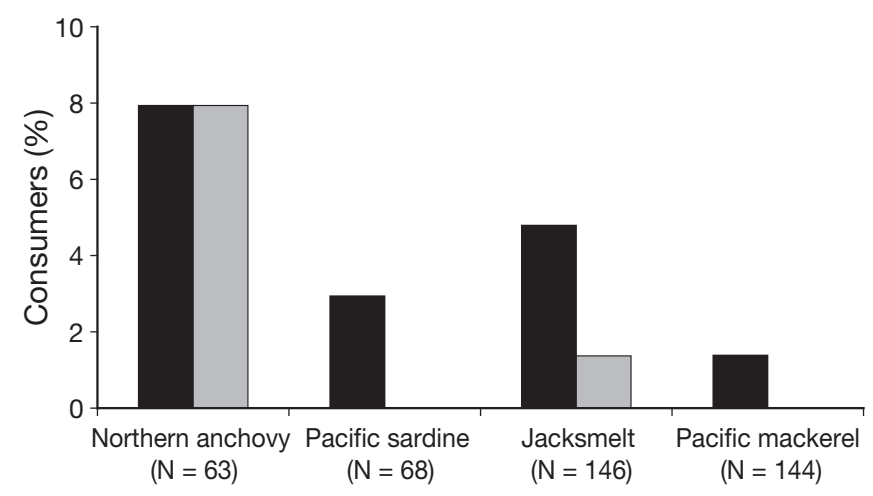

Fig. 3. Percentage of consumers of fishes caught at the Santa Cruz Wharf who do not remove viscera before preparing fish for consumption (black bars) and who eat viscera (grey bars) 


\section{DA in fish viscera and seawater}

DA in vessel-caught pelagic planktivores (northern anchovy and Pacific sardine) was significantly associated with DA measured in seawater samples collected offshore at M1 or nearshore at the SCW within $7 \mathrm{~d}$ of fish capture $\left(\chi_{1,71}^{2}=71, p<0.01\right.$; Figs. 4 A, B \& 5A-C). We were unable to test if the presence of DA in wharfcaught pelagic planktivores (anchovy) was significantly associated with the presence or absence of DA at M1 or SCW due to the small number of times that planktivores were caught at the wharf.

DA in pelagic omnivores (jacksmelt and Pacific mackerel) was significantly associated with particulate DA measured in seawater samples collected at the SCW $\left(\chi_{1,39}^{2}=20.14, p<0.01\right)$, but not associated with DA measured offshore at M1 $\left(\chi_{1,14}^{2}=6.46, p=0.142\right)$ within $7 \mathrm{~d}$ of fish capture (Figs. 4A,B \& 5A,D). Additionally, DA in viscera of benthic feeders (rainbow surfperch, speckled sanddab and staghorn sculpin) was significantly associated with DA levels measured in seawater at the SCW $\left(\chi^{2}{ }_{1,31}=5.16, p=0.04\right)$ and at M1 $\left(\chi^{2}{ }_{1,22}=7.60, p=0.02\right)$ within $7 \mathrm{~d}$ of fish capture (Figs. 4A,B \& 5A,D). Although some of these associations were statistically significant, DA was also detected in pelagic omnivores and benthic feeders when no DA was detected in surface waters (i.e. false negatives). The opposite association (i.e. false positives: where DA was detected in surface waters, but not detected such fish feeding groups) was also observed (Fig. 4A,B).

In addition, ANOVA results showed that mean DA levels in the viscera of fish caught when DA was detected in the seawater significantly differed among fish feeding groups $\left(F_{2,71}=122.44, \mathrm{p}<0.01\right.$; Fig. 6$)$. Pairwise comparison analysis further verified that DA levels in pelagic planktivores significantly differed from DA levels in pelagic omnivores $(p<0.01)$ and benthic feeders $(p<0.01)$, but the latter 2 groups did not significantly differ from each other $(p=0.71)$. Indeed, pelagic planktivores were the only group that had mean DA levels in viscera $>20 \mu \mathrm{g} \mathrm{g}^{-1}$.

\section{DA in mussels and fish}

DA was never detected in mussels collected within $7 \mathrm{~d}$ of capture of vessel- or wharf-caught DA-containing planktivorous fish (Fig. 4C). In fact, DA levels above the safety limit occurred in viscera of planktivores prior to the detection or non-detection (i.e. false negatives) of DA in mussels in April 2007 and in August 2008, respectively (Figs. 4C \& 5C-E). Results of the $\chi^{2}$ test

Table 1. Feeding habit groups for fish species caught (grouped by feeding habit), number of specimens analyzed for stomach contents and typical food items observed in viscera

\begin{tabular}{|c|c|c|}
\hline Species & $\mathrm{N}$ & Food items observed \\
\hline \multicolumn{3}{|l|}{ Pelagic planktivores } \\
\hline Northern anchovy Engraulis mordax & 24 & $\begin{array}{l}\text { Centric and pennate diatoms (including fragments of Pseudo-nitzschia } \\
\text { spp.), dinoflagellates, silicoflagellates, tintinnids }\end{array}$ \\
\hline Pacific sardine Sardinops sagax & 8 & $\begin{array}{l}\text { Centric and pennate diatoms (including fragments of Pseudo-nitzschia } \\
\text { spp.) }\end{array}$ \\
\hline \multicolumn{3}{|l|}{ Pelagic onmivores } \\
\hline Jacksmelt Atherinopsis californiensis & 21 & $\begin{array}{l}\text { Crustaceans (barnacles, amphipods/isopods, mysids), centric diatoms, } \\
\text { fish bones, macroalgae, parasitic worms }{ }^{\text {a }} \text {, sediment }\end{array}$ \\
\hline Pacific mackerel Scomber japonicus & 5 & Crustaceans, macroalgae, parasitic worms ${ }^{\mathrm{a}}$ \\
\hline \multicolumn{3}{|l|}{ Benthic feeders } \\
\hline Barred surfperch Amphistichus argenteus & 3 & Clam/mussel shells, crustaceans, parasitic worms ${ }^{\mathrm{a}}$, sediment \\
\hline Rainbow surfperch Hypsurus caryi & 1 & Clam/mussel shells, crustaceans, sediment \\
\hline Shiner surfperch ${ }^{b}$ & 9 & $\begin{array}{l}\text { Clam/mussel shells, crustaceans (amphipods/isopods, mysids), copepods, } \\
\text { foraminifera, Cymatogaster aggregata macroalgae, parasitic worms }{ }^{\mathrm{a}} \text {, } \\
\text { sediment }\end{array}$ \\
\hline Speckled sanddab ${ }^{\mathrm{b}}$ Citharichthys stigmaeus & 16 & $\begin{array}{l}\text { Clam/mussel shells, crustaceans (mysids), macroalgae, polychaetes, } \\
\text { sediment }\end{array}$ \\
\hline Spotfin surfperch ${ }^{\mathrm{b}}$ Hyperprosopon anale & 1 & Crustaceans \\
\hline Staghorn sculpin ${ }^{\mathrm{b}}$ Leptocottus armatus & 55 & $\begin{array}{l}\text { Crustaceans (isopods/amphipods, mysids), macroalgae, parasitic worms }{ }^{\mathrm{a}}{ }_{\text {, }} \\
\text { sediment }\end{array}$ \\
\hline White croaker ${ }^{\mathrm{b}}$ Genyonemus lineatus & 15 & $\begin{array}{l}\text { Clam/mussel shells, crustaceans (isopods/ amphipods, mysids), centric } \\
\text { diatoms, fish bones, macroalgae, parasitic worms }{ }^{\text {a }} \text {, polychaetes, } \\
\text { sediment }\end{array}$ \\
\hline
\end{tabular}


Table 2. Domoic acid (DA) levels $\left(\mu \mathrm{g} \mathrm{g}^{-1}\right.$ ) in viscera samples of 11 fish species. $\mathrm{n}$ : number of samples with detectable levels of $\mathrm{DA}_{i} \mathrm{~N}$ : total number of samples analyzed. -: not detected

\begin{tabular}{|c|c|c|c|c|c|c|}
\hline Species & Range & Mean & Median & $\mathrm{SD}$ & $\mathrm{n}$ & $\mathrm{N}$ \\
\hline \multicolumn{7}{|l|}{ Pelagic planktivores } \\
\hline Northern anchovy & $9-148$ & 71 & 54 & 67 & 5 & 18 \\
\hline Pacific sardine & $15-110$ & 37 & 36 & 15 & 51 & 51 \\
\hline \multicolumn{7}{|l|}{ Pelagic omnivores } \\
\hline Jacksmelt & $2.5-27$ & 7.3 & 4.5 & 7.8 & 9 & 39 \\
\hline Pacific mackerel $^{\mathrm{a}}$ & $1.5-2.3$ & 1.9 & 1.9 & 0.3 & 7 & 9 \\
\hline \multicolumn{7}{|l|}{ Benthic feeders } \\
\hline Barred surfperch & - & - & - & - & 0 & 4 \\
\hline Rainbow surfperch ${ }^{a}$ & - & 1.5 & - & - & 1 & 1 \\
\hline Shiner surfperch & - & - & - & - & 0 & 2 \\
\hline Speckled sanddab & $2.9-4.5$ & 3.7 & 3.7 & 1.1 & 2 & 9 \\
\hline Spotfin surfperch & - & - & - & - & 0 & 1 \\
\hline Staghorn sculpin ${ }^{\mathrm{a}}$ & $0.25-0.4$ & 0.3 & 0.3 & 0.1 & 3 & 21 \\
\hline White croaker & - & - & - & - & 0 & 5 \\
\hline
\end{tabular}

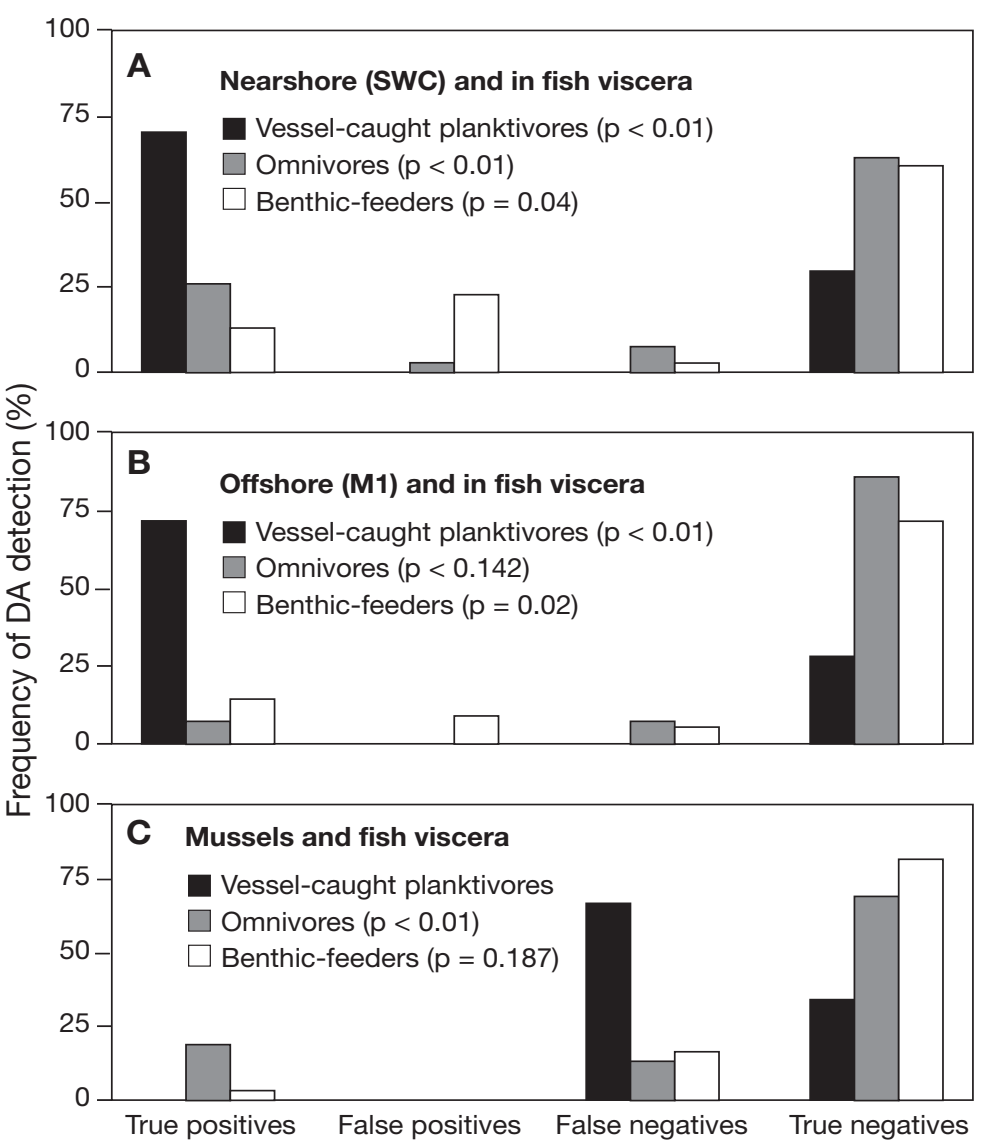

Fig. 4. Percent frequency of different associations between domoic acid (DA) detection and (A) nearshore waters (Santa Cruz Wharf [SCW]), (B) offshore waters (M1) and (C) SCW mussels and fish viscera. True positives: DA detected in water/mussel and fish; false positives: DA detected in water/mussel, but not in fish; false negatives: DA not detected in water/mussel, but detected in fish; true negatives: DA not detected in water/mussels and fish. Fisher's exact test p-values indicate whether DA detection in fish was significantly associated with DA in mussels in nearshore and offshore waters indicated that the presence of DA in mussels collected within $7 \mathrm{~d}$ of fish capture was not significantly associated with the presence of DA in the viscera of benthic feeding fish $\left(\chi_{1,33}^{2}=4.73, \mathrm{p}=0.187\right)$. Moreover, DA was detected in benthic feeders when DA was not detected in mussels (i.e. false negatives) in $16 \%$ of the correlated samples (Fig. 4C). However, the detection of DA in mussels was significantly associated to DA in the viscera of pelagic omnivores $\left(\chi_{1,48}^{2}=19.2, \mathrm{p}<0.05\right)$, even though DA was detected in the viscera of pelagic omnivores when no DA was detected in mussels (i.e. false negatives) (Figs. 4C \& 5D,E).

\section{DA in fish body parts}

DA was detected in $31 \%$ of the muscle tissue samples from wharf-caught anchovy and $72 \%$ of the muscle tissue samples from vessel-caught sardines that were dissected within $7 \mathrm{~h}$ of capture, but DA was never detected in jacksmelt muscle tissue $(\mathrm{N}=7)$. Mean DA levels in anchovy and sardine muscle tissue were $1.7 \mathrm{\mu g} \mathrm{g}^{-1}(\mathrm{~N}=9, \mathrm{SD}=$ 4.0) and $0.5 \mu \mathrm{g} \mathrm{g}^{-1}(\mathrm{~N}=22, \mathrm{SD}=0.6)$, respectively. In addition, linear regression results indicate that DA levels measured in the viscera and muscle tissue of the same individual sardine specimens were not significantly related $\left(F_{1,16}=2.90, \mathrm{r}^{2}=0.15\right.$, $\mathrm{p}=0.107$ ).

\section{DA degradation and diffusion within fish}

ANOVA results showed that the log of DA concentration in sardine viscera was significantly lower after storage of whole sardines for 11 mo than DA levels in viscera of sardines that were dissected $5 \mathrm{~h}$ upon capture (Table 3 ). We did not observe a significant change between the log of DA concentration in muscle tissue of sardines that were kept frozen whole for 11 mo after the capture date and the log of DA concentration in muscle tissue of sardines that were dissected $7 \mathrm{~h}$ after capture. In addition, total (i.e. viscera and muscle tissue) DA concentration in sardines was significantly lower after storage for $11 \mathrm{mo}$ at $-20^{\circ} \mathrm{C}$ than total DA levels in sardines dissected $7 \mathrm{~h}$ after capture. 

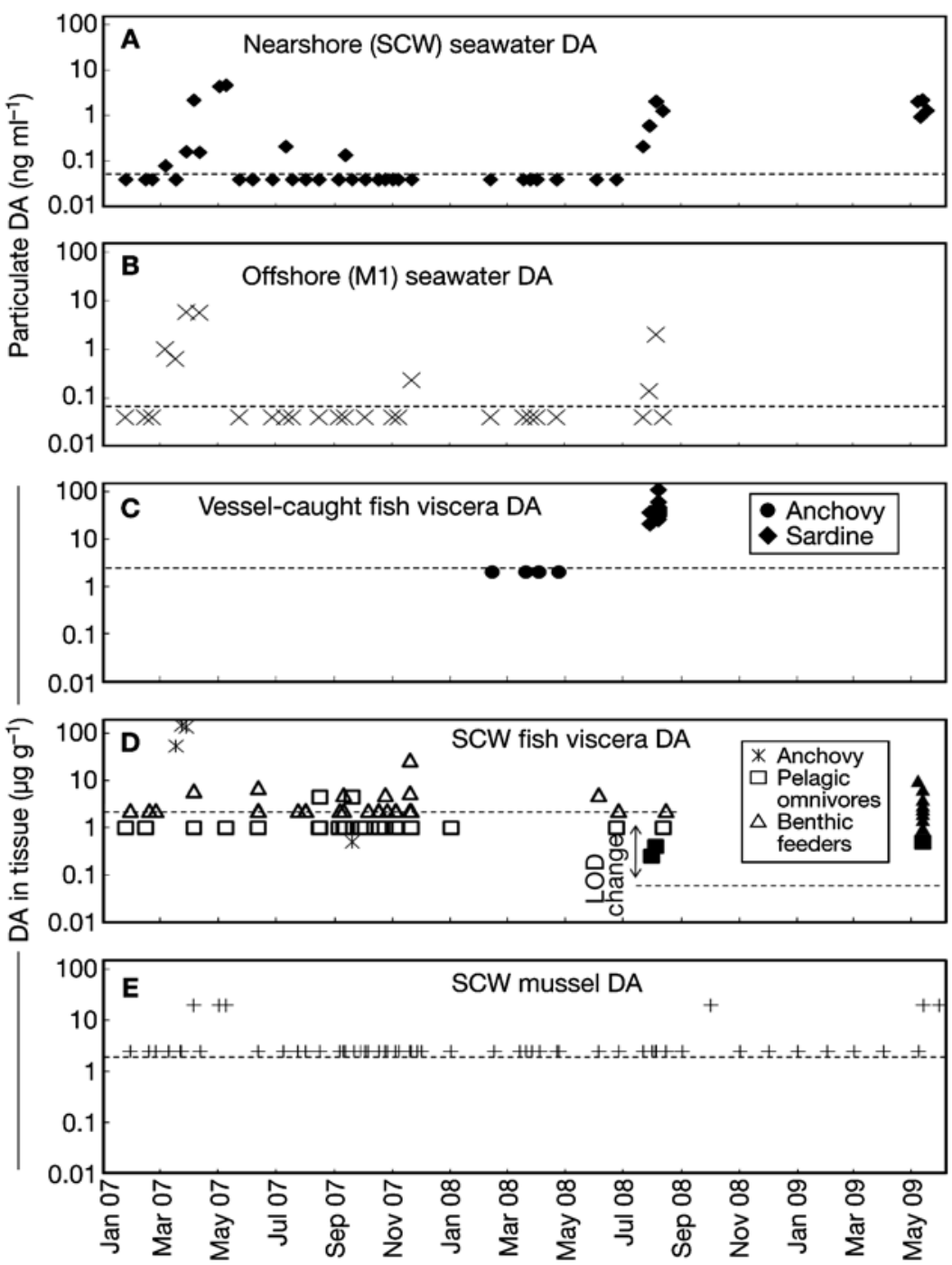

Fig. 5. Domoic acid (DA) levels in (A) seawater at the Santa Cruz Wharf (SCW), (B) seawater at M1, (C) viscera of vessel-caught fish, (D) viscera of wharf-caught fish and (E) SCW mussels. Dashed line indicates HPLC limit of detection (LOD). Filled symbols in (D) show samples where ELISA was used and the step change in LOD. A DA constant, a value below the detection limit, was added to allow display of values in log format

\section{DISCUSSION}

The goal of the present study was to determine whether or not anglers were exposed to DA through the consumption of their catch, since fish are DA vectors to their aquatic predators. An additional goal was to determine whether the presence of DA in local seawater or in mussels was predictive of DA in recreationally caught fish at the SCW. We have shown that dietary exposure of SCW anglers to DA is dependent on the fish species and body parts consumed, catch storage methods and the presence of DA in the seawater.
The variability of DA levels among fish species appeared to be related to their different feeding habits. Accordingly, DA levels in viscera of pelagic planktivores, which can directly feed on the DA-producing Pseudo-nitzschia, were significantly higher than DA levels in viscera of pelagic omnivores and benthic feeders collected at times when DA was detected in seawater. Additionally, planktivores were the only group whose mean viscera DA levels exceeded the safety limit of $20 \mu \mathrm{g}$ DA $\mathrm{g}^{-1}$ set by the US Food and Drug Administration.

DA distribution in fish viscera and muscle tissue was uneven. DA levels in muscle tissue were up to 2 orders of magnitude lower than in the viscera of anchovy and sardine, and were undetectable in jacksmelt muscle tissue. We further showed that DA in muscle tissue of sardines was not significantly correlated with DA levels in their viscera. The low DA levels in muscle tissue may be the residual DA after the 'first pass' renal and biliary excretion (Lefebvre et al. 2007). Accordingly, low or zero absorption of DA from the gastrointestinal tract has been documented in planktivorous fishes, mice and monkeys (Inverson et al 1989, Truelove et al 1996, Lefebvre et al 2001).

Catch storage methods may alter the amount of toxin to which anglers are exposed since total DA levels in fish and in fish viscera declined significantly with storage time (Table 3). However, muscle tissue DA levels did not significantly change after storage even though mean DA levels in muscle tissue of sardines were higher after storage. These results suggest that some of the DA diffused from the viscera into the muscle, but that the degradation rate is faster than the diffusion rate. DA degradation due to storage has also been documented in particulate DA samples of phytoplankton stored in GF/F filters for $>2$ mo at +4 and $-20^{\circ} \mathrm{C}$ (Lane \& Kudela 2007) and in aqueous solutions stored at $-12^{\circ} \mathrm{C}$ (Quilliam 2003). We present the first data related to measurements of DA diffusion and degradation in fish over a time scale of months.

The presence of DA in local waters (nearshore and offshore) was significantly associated with the presence of DA in the viscera of all 3 fish groups. The only 


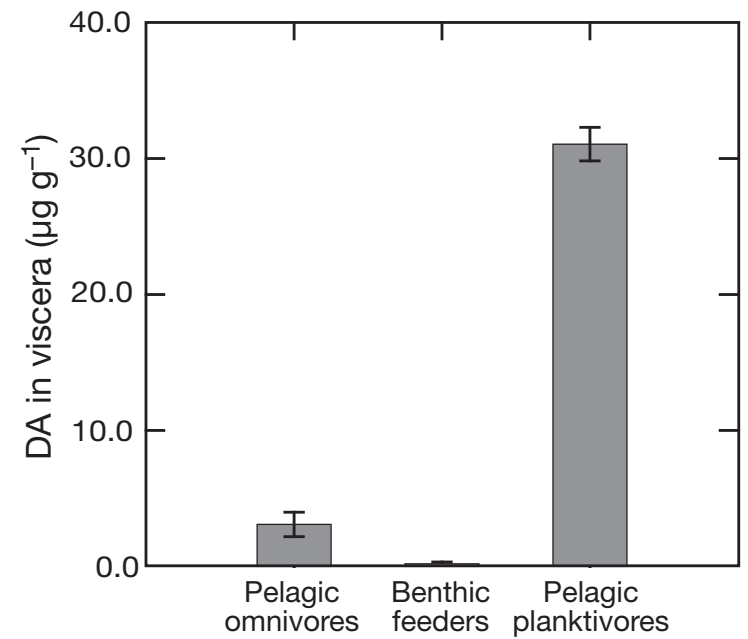

Fig. 6. Mean $( \pm \mathrm{SE})$ domoic acid (DA) levels in the viscera of pelagic omnivores $(N=11)$, benthic feeders $(N=12)$ and pelagic planktivores $(\mathrm{N}=51)$ caught when DA was detected in the water

non-significant association was observed between DA in pelagic omnivores and DA measured in offshore waters. This result was probably due to the small sample size. The significant associations indicate that fish with different dietary habits and caught within $7 \mathrm{~d}$ of the DA detection in local surface waters are likely to contain detectable DA.

Moreover, sediment and benthic invertebrate prey may represent an additional source of DA contamination for pelagic omnivores and benthic feeders when DA is not detected in the water. False negatives (Fig. 4A,B) were likely observed for these fish groups since they can feed on benthic invertebrates or sediment. Sediments are effective adsorbents of DA and can act as DA reservoirs after a toxic Pseudo-nitzschia bloom has subsided (Burns \& Ferry 2007). Sediment was found in the viscera of all pelagic omnivores and benthic feeders analyzed in the present study, except for Pacific mackerel (Table 1). Additionally, DA has been detected in innkeeper worms Urechis sp., rock crabs, acorn barnacles Balanus glandula and B. nubulis, and sea anemones Aiptasia sp. collected when no toxic Pseudo-nitzschia or DA were detected in the seawater column, implying that some invertebrates are

Table 3. Sardinops sagax. Mean $( \pm \mathrm{SD})$ domoic acid (DA) levels $\left(\mu \mathrm{g} \mathrm{g}^{-1}\right)$ in whole and parts of fresh-caught $(7 \mathrm{~h}$ after catch, $\mathrm{N}=22$ ) versus frozen (11 mo after catch, $\mathrm{N}=5$ ) sardines

\begin{tabular}{|lccrr|}
\hline Sample & Fresh & Frozen & $F_{1,26}$ & \multicolumn{1}{c|}{$\mathrm{p}$} \\
\hline Viscera & $38 \pm 9.0$ & $12 \pm 4.6$ & 129.14 & $<0.01$ \\
Muscle tissue & $0.5 \pm 0.6$ & $1.2 \pm 1.0$ & 1.52 & 0.22 \\
Whole sardine & $4.6 \pm 1.3$ & $2.4 \pm 0.6$ & 19.83 & $<0.01$ \\
\hline
\end{tabular}

able to retain DA after the toxic event, or that they access DA-contaminated sediment or organisms after a water column event has ended (Cheung 2007, Garcia et al. 2007, Vigilant 2007, Kvitek et al. 2008). In addition, pelagic omnivores and benthic feeders were sometimes found not to be contaminated with DA when DA was detected in the water (i.e. false positives, Fig. 4A,B), which may further indicate that species within these groups feed on prey that may or may not be contaminated with DA at the time of feeding.

California mussels did not reliably predict the presence of DA in fish. Three factors may explain the lack of a significant association between DA in the viscera of fish and in mussels, and why DA was sometimes detected in omnivorous fish, but not in mussels. (1) Mussels have faster depuration rates (50 to $87 \% \mathrm{~d}^{-1}$ ) and may reflect the immediate presence of DA in water, whereas fish can retain DA for longer periods (with depuration rates of $30 \% \mathrm{~d}^{-1}$ ) (Novaczek et al. 1992, Lefebvre et al. 2007, Krogstad et al. 2009). (2) Mussels and fish feed differently: mussels are sessile benthic organisms that filter the toxic cells out of the seawater at a single location, whereas the fish species analyzed in the present study are highly mobile and may acquire DA through routes other than filter feeding. (3) DA is more readily detected in fish viscera (as it represents source material that leads to contamination), and if comparisons were done using DA levels in whole fish bodies instead of fish viscera, we would have not detected DA in fish that had low viscera DA levels (i.e. pelagic omnivorous and benthic feeding fish) at times when DA was not detected in mussels.

DA exposure levels calculated for anglers were equivalent to asymptomatic doses (i.e. DA levels are measurable in fish, but below the dose that results in recognizable acute effects attributed to ASP; Table 4).

Table 4. Domoic acid (DA) dose intake by Santa Cruz Wharf anglers and percentage of lowest adverse effects level (LOAEL) dose of $1 \mathrm{mg} \mathrm{kg}^{-1}$ body weight that causes amnesic shellfish poisoning (ASP) (Toyofuku 2006). Dose calculations based on a $50 \mathrm{~g} \mathrm{~d}^{-1}$ fish meal (standard amount of fish consumed by California anglers; OEHHA 2001)

\begin{tabular}{|lccc|}
\hline $\begin{array}{l}\text { Part consumed } \\
\text { Species }\end{array}$ & $\begin{array}{c}\text { Max. DA } \\
\text { concentration } \\
\left(\mu \mathrm{g} \mathrm{g}^{-1}\right)\end{array}$ & $\begin{array}{c}\text { DA dose } \\
\left.\left({\mathrm{mg} 5 \mathrm{~g}^{-1} \text { of }}_{\text {fish meal }}\right)^{-1}\right)\end{array}$ & $\begin{array}{c}\text { Percent } \\
\text { of } \\
\text { LOAEL }\end{array}$ \\
\hline Whole fish & & & \\
$\quad$ Northern anchovy & 28.3 & 1.43 & 2.4 \\
Pacific sardine & 12.8 & 0.64 & 1.1 \\
Jacksmelt & 2.3 & 0.11 & 0.2 \\
Pacific mackerel & 0.2 & 0.01 & 0.02 \\
Muscle tissue & & & \\
$\quad$ Northern anchovy & 10.8 & 0.54 & 0.9 \\
Pacific sardine & 1.8 & 0.09 & 0.2 \\
\hline
\end{tabular}


The highest DA dose that anglers would likely ingest would result from consuming freshly caught whole anchovies or sardines, assuming they consumed $50 \mathrm{~g}$ of fish (the standard amount of fish ingested by California anglers; OEHHA 2001). Such a dose corresponds to 2.4 and $1.1 \%$, for consumption of anchovies and sardines, respectively, of the DA dose $\left(1 \mathrm{mg} \mathrm{kg}^{-1}\right)$ that can induce the lowest adverse effects of ASP in adults of $60 \mathrm{~kg}$ (Toyofuku 2006). Anglers who consume only the muscle tissue of anchovy or sardine (i.e. those who remove the viscera before eating the fish) and whole jacksmelt would be exposed to even lower DA doses, with even lower levels ingested by consumers of Pacific mackerel.

It is unknown if the ingestion of asymptomatic DA doses can harm humans over the long term. Low DA levels $\left(0.002\right.$ to $\left.0.11 \mathrm{\mu g} \mathrm{g}^{-1}\right)$ detected in the urine of California sea lions have been associated with a novel neurological syndrome characterized by epilepsy (Goldstein et al. 2008). More recently, Lefebvre et al. (2009) showed that DA doses below those that cause observable signs of behavioral injury in zebrafish can downregulate several genes involved in important biochemical processes, suggesting potential neurological risk associated with asymptomatic DA exposures. In contrast, experiments with rats have demonstrated that low DA doses can precondition the brain and induce tolerance against higher DA doses in young, but not aged, rats (Kerr et al. 2002, Hesp et al. 2004). In humans, the most susceptible individuals to low DA doses may include pregnant and nursing women, since experiments with rats showed that (1) low DA doses may be transferred through milk and placenta, and accumulated in the amniotic fluid of pregnant rats and the brain of prenatal rats (Maucher \& Ramsdell 2005, 2007); and (2) DA can reach the brain without restriction, causing neurological and behavior effects later in the life for prenatal rats (Dakshinamurti et al. 1993, Levin et al. 2005, Maucher \& Ramsdell 2007). In humans, the elderly ( $>65 \mathrm{yr}$ ) are most susceptible, since DA is cleared from the plasma through the kidneys (Suzuki \& Hierlihy 1993), and old individuals are thought to have reduced ability to eliminate DA through the renal system (Xi et al. 1997, Pulido 2008). Additionally, higher DA levels of 275,588 and $1815 \mu \mathrm{g} \mathrm{g}^{-1}$ have been detected in viscera of jacksmelt, sardine and anchovy caught at other times in Monterey Bay (Lefebvre et al. 2002a,b). Thus, SCW anglers could be exposed to even higher DA doses than those reported here.

\section{CONCLUSIONS}

The present study showed that SCW anglers can be exposed to asymptomatic DA doses through consumption of their catch. DA levels of exposure are depen- dent on the fish species and parts consumed, as well as on storage methods and the presence of particulate DA in the water at the time the fish is caught. In addition, we determined that California mussels do not adequately predict DA levels in fish. To minimize DA exposure, anglers should eviscerate (clean) their fish before consumption, since the highest DA levels were found in the viscera of freshly captured fish. Furthermore, DA is heat-stable and may not be completely eliminated from fish tissue when cooked (McCarron \& Hess 2006). For pelagic planktivores, where DA levels were found in both viscera and muscle tissue, the removal of the viscera may not be sufficient to eliminate exposure to DA. Thus, consumption of muscle tissue of planktivorous fish caught during toxic blooms may result in low-level DA exposure; the consequences of such asymptomatic doses are worrisome, given recent evidence from studies with other mammals.

Acknowledgements. We thank the UCSC undergraduate volunteers who assisted us with fish collection and surveys; V. Long, survey coordinator; V. Vigilant for HPLC analysis training; G. Langlois (CDPH) for information on biotoxin monitoring; and $\mathrm{K}$. Roberts for ELISA analysis training. This paper was prepared under NOAA grant nos. NA04OAR4170038 and NA08OAR4170669, California Sea Grant College Program Project no. R-MA-43, through NOAA's National Sea Grant College Program, US Department of Commerce; and was supported in part by the California State Resources Agency. The statements, findings, conclusions and recommendations are those of the authors and do not necessarily reflect the views of California Sea Grant or the US Department of Commerce. Additional funding was provided by the Peace Scholarship Fund and the William C. Bannerman Foundation.

\section{LITERATURE CITED}

Bates SS, Bird CJ, de Freitas ASW, Foxall R and others (1989) Pennate diatom Nitzschia pungens as the primary source of domoic acid, a toxin in shellfish from eastern Prince Edward Island, Canada. Can J Fish Aquat Sci 46:1203-1215

Burns JM, Ferry JL (2007) Adsorption of domoic acid to marine sediments and clays. J Environ Monit 9:1373-1377

Busse LB, Venrick EL, Antrobus R, Miller PE and others (2006) Domoic acid in phytoplankton and fish in San Diego, CA, USA. Harmful Algae 5:91-101

Cailliet GM, Burton EJ, Cope JM, Kerr LA and others (2000) Biological characteristics of nearshore fishes of California: a review of existing knowledge and proposed additional studies. California Department of Fish and Game, available at www.dfg.ca.gov/marine/lifehistories/index.asp

Cheung IS (2007) Domoic acid toxicity in rock crabs, Cancer antennarius and Cancer productus in Monterey Bay, California, USA and potential human toxin exposure in crab hepatopancreas. MS thesis, University of California Santa Cruz

> Connelly NA, Knuth BA, Brown TL (1996) Sportfish consumption patterns of Lake Ontario anglers and the relationship to health advisories. N Am J Fish Manage 16:90-101

Dakshinamurti K, Sahrma SK, Sundaram M (1993) Hippo- 
campal changes in developing postnatal mice following intrauterine exposure to domoic acid. J Neurosci 13: 4486-4495

Fire SE, Silver MW (2005) Domoic acid in the Santa Cruz wharf fishery. Calif Fish Game 91:179-192

Garcia S, Mazzillo F, Silver MW (2007) Domoic acid in benthic community of the Santa Cruz Wharf in Monterey Bay, California, USA. Fourth Symposium on Harmful Algae in the US, Woods Hole, MA, p 130

Goldstein T, Mazet JAK, Zabka TS, Langlois GW and others (2008) Novel symptomatology and changing epidemiology of domoic acid toxicosis in California sea lions (Zalophus californianus): an increasing risk to marine mammal health. Proc Biol Sci 275:267-276

Hatfield CL, Wekell JC, Gauglitz EJ Jr, Barnett HJ (1994) Salt clean-up procedure for the determination of domoic acid by HPLC. Nat Toxins 2:206-211

> Hesp BR, Wrightson T, Mullaney I, Kerr DS (2004) Kainate receptor agonists and antagonists mediate tolerance to kainic acid and reduce high-affinity GTPase activity in young, but not aged, rat hippocampus. J Neurochem 90:70-79

Iverson F, Truelove J, Nera E, Tryphonas L, Campbell J, Lok E (1989) Domoic acid poisoning and mussel-associated intoxication: preliminary investigations into the response of mice and rats to toxic mussel extract. Food Chem Toxicol 27:377-384

Jeffery B, Barlow T, Moizer K, Paul S, Boyle C (2004) Amnesic shellfish poison. Food Chem Toxicol 42:545-557

> Jester R, Lefebvre K, Langlois GW, Vigilant V, Baugh K, Silver MW (2009) A shift in the dominant toxin-producing algal species in central California alters phycotoxins in food webs. Harmful Algae 8:291-298

Jones K (1992) Pier fishing in California. Marketscope Books, Aptos, CA

Kerr DS, Razak A, Crawford N (2002) Age-related changes in tolerance to the marine algal excitotoxin domoic acid. Neuropharmacology 43:357-366

Krogstad FTO, Griffith WC, Vigoren EM, Faustman EM (2009) Re-evaluating blue mussel depuration rates in 'Dynamics of the phycotoxin domoic acid: accumulation and excretion in two commercially important bivalves'. J Appl Phycol 21:745-746

Kvitek RG, Goldberg JD, Smith JG, Doucette GJ, Silver MW (2008). Domoic acid contamination within eight representative species from the benthic food web of Monterey Bay, California, USA. Mar Ecol Prog Ser 367:35-37

Lane JQ, Kudela R (2007) Degradation of domoic acid under common storage conditions. Fourth Symposium on Harmful Algae in the US, Woods Hole, MA, p 130

Lefebvre KA, Powell CL, Busman M, Doucette GJ and others (1999) Detection of domoic acid in northern anchovies and California sea lions associated with an unusual mortality event. Nat Toxins 7:85-92

Lefebvre KA, Dovel SL, Silver MW (2001) Tissue distribution and neurotoxic effects of domoic acid in a prominent vector species, the northern anchovy Engraulis mordax. Mar Biol 138:693-700

Lefebvre KA, Silver MW, Coale SL, Tjeerdema RS (2002a) Domoic acid in planktivorous fish in relation to toxic Pseudo-nitzschia cell densities. Mar Biol 140:625-631

Lefebvre KA, Bargu S, Kieckhefer T, Silver MW (2002b) From sanddabs to blue whales: the pervasiveness of domoic acid. Toxicon 40:971-977

> Lefebvre KA, Noren DP, Schultz IR, Bogard SM, Wilson J, Eberhart BTL (2007) Uptake, tissue distribution and excretion of domoic acid after oral exposure in coho salmon (Oncorhynchus kisutch). Aquat Toxicol 81:266-274
Lefebvre KA, Tilton SC, Bammler TK, Beyer RP and others (2009) Gene expression profiles in zebrafish brain after acute exposure to domoic acid at symptomatic and asymptomatic doses. Toxicol Sci 107:65-77

> Levin ED, Pizarro K, Pang WG, Harrison J, Ramsdell JS (2005) Persisting behavioral consequences of prenatal domoic acid exposure in rats. Neurotoxicol Teratol 27:719-725

Litaker R, Stewart TN, Eberhart BTL, Wekell JC and others (2008) Rapid enzyme-linked immunosorbent assay for detection of the algal toxin domoic acid. J Shellfish Res 27:1301-1310

> Maucher JM, Ramsdell JS (2005) Domoic acid transfer to milk: evaluation of a potential route of neonatal exposure. Environ Health Perspect 113:461-464

Maucher JM, Ramsdell JS (2007) Maternal-fetal transfer of domoic acid in rats at two gestational time points. Environ Health Perspect 115:1743-1746

> McCarron P, Hess P (2006) Tissue distribution and effects of heat treatments on the content of domoic acid in blue mussels, Mytilus edulis. Toxicon 47:473-479

> Novaczek I, Madhyastha MS, Ablett RF, Donald A, Johnson G, Nijjar MS, Sims DE (1992) Depuration of domoic acid from live blue mussels (Mytilus edulis). Can J Fish Aquat Sci 49:312-318

OEHHA (Office of Environmental Health Hazard Assessment) (2001) Chemicals in fish: consumption of fish and shellfish in California and the United States. Pesticide and Environmental Toxicology Section, OEHHA, California Protection Agency, Oakland, CA

Perl TM, Bedard L, Kosatsky T, Hockin JC, Todd ECD, Remis RS (1990) An outbreak of toxic encephalopathy caused by eating mussels contaminated with domoic acid. N Engl J Med 322:1775-1780

Pocklington R, Milley JE, Bates SS, Bird CJ, de Freitas ASW, Quilliam MA (1990) Trace determination of domoic acid in seawater and phytoplankton by high-performance liquid chromatography of the fluorenylmethoxycarbonyl (FMOC) derivative. Int J Environ Anal Chem 38:351-368

> Pulido O (2008) Domoic acid toxicologic pathology: a review. Mar Drugs 6:180-219

Quilliam MA (2003) Chemical methods for domoic acid, the amnesic shellfish poisoning (ASP) toxin. In: Hallegraeff GM, Blackburn SI, Bolch CJ, Lewis RJ (eds) Harmful algal blooms 2000. Intergovernmental Oceanographic Commission of UNESCO, Paris, p 247-265

Quilliam MA, Xie M, Hardstaff WR (1995) A rapid extraction and cleanup for liquid-chromatographic determination of domoic acid in unsalted seafood. J AOAC Int 78: $543-554$

RecFIN (2009) RecFIN database. Pacific States Marine Recreational Fisheries Monitoring, available at www.recfin.org

Scholin CA, Gulland F, Doucette GJ, Benson S and others (2000) Mortality of sea lions along the central California coast linked to a toxic diatom bloom. Nature 403:80-84

SFEI (San Francisco Estuary Institute) (2000) San Francisco Bay Seafood Consumption Study. SFEI, Oakland, CA, available at www.sfei.org/rmp/sfcindex.htm

Sierra-Beltran AP, Cruz A, Nunez E, Del Villar LM, Cerecero J, Ochoa JL (1998) An overview of the marine food poisoning in Mexico. Toxicon 36:1493-1502

SCCWRP \& MBC (Southern California Coastal Water Research Project, MBC Applied Environmental Sciences) (1994) Santa Monica Bay Seafood Consumption Study. Santa Monica Bay Restoration Project, Monterey Park, CA

Suzuki CAM, Hierlihy SL (1993) Renal clearance of domoic acid in the rat. Food Chem Toxicol 31:701-706

Toyofuku H (2006) Joint FAO/WHO/IOC activities to provide 
scientific advice on marine biotoxins (research report). Mar Pollut Bull 52:1735-1745

Truelove J, Mueller R, Pulido O, Iverson F (1996) Subchronic toxicity study of domoic acid in the rat. Food Chem Toxicol 34:525-529

US EPA (1998) Guidance for conducting fish and wildlife consumption surveys. Document No. EPA 823-B-98-007. US Environmental Protection Agency, Washington, DC, available at www.epa.gov/fishadvisories/files/fishguid.pdf

Vale P, Sampayo MAM (2001) Domoic acid in Portuguese shellfish and fish. Toxicon 39:893-904

Vigilant VL (2007) The occurrence of the harmful algae toxin domoic acid, in nearshore and offshore benthic communities of Monterey Bay, California. PhD dissertation, University of California Santa Cruz

> Vigilant VL, Silver MW (2007) Domoic acid in benthic flatfish on the continental shelf of Monterey Bay, California, USA. Mar Biol 151:2053-2062

Editorial responsibility: Matthias Seaman, Oldendorf/Luhe, Germany
Waldichuk M (1989) Amnesic shellfish poison. Mar Pollut Bull 20:359-360

West PC (1992) Invitation to poison? Detroit minorities and toxic fish consumption from the Detroit River. In: Bryant B, Mohai P (eds) Race and the incidence of environmental hazards: a time for discourse. Westview Press, Boulder, CO, p 96-99

Work TM, Barr B, Beale AM, Fritz L, Quilliam MA, Wright JLC (1993) Epidemiology of domoic acid poisoning in brown pelicans (Pelecanus occidentalis) and Brandt cormorants (Phalacrocorax penicillatus) in California. J Zoo Wildl Med 24:54-62

> Wright JLC, Boyd RK, de Freitas ASW, Falk M and others (1989) Identification of domoic acid, a neuroexcitatory amino acid, in toxic mussels from eastern Prince Edward Island. Can J Chem 67:481-490

Xi D, Peng YG, Ramsdell JS (1997) Domoic acid is a potent neurotoxin to neonatal rats. Nat Toxins 5:74-79

Submitted: December 16, 2009; Accepted: February 17, 2010 Proofs received from author(s): March 20, 2010 